\title{
Ontogeny of Iodothyronine Deiodinases in Human Liver*
}

\author{
KERRY RICHARD, ROBERT HUME, ELLEN KAPTEIN, JO P. SANDERS, \\ HANS VAN TOOR, WOUTER W. DE HERDER, JAN C. DEN HOLLANDER, \\ ERIC P. KRENNING, AND THEO J. VISSER
}

\begin{abstract}
Department of Internal Medicine III, Erasmus University Medical School (K.R., E.K., J.P.S., H.v.T., W.W.d.H., E.P.K., T.J.V.), Rotterdam, The Netherlands; Department of Obstetrics and Gynaecology, University of Dundee, Ninewells Hospital and Medical School (K.R., R.H.), Dundee, United Kingdom; Department of Pathology, Erasmus University Medical School (J.C.d.H.), Rotterdam, The Netherlands; and Department of Nuclear Medicine, University Hospital Dijkzigt (E.P.K.), Rotterdam, The Netherlands
\end{abstract}

\begin{abstract}
The role of the deiodinases D1, D2, and D3 in the tissue-specific and time-dependent regulation of thyroid hormone bioactivity during fetal development has been investigated in animals but little is known about the ontogeny of these enzymes in humans. We analyzed D1, D2, and D3 activities in liver microsomes from 10 fetuses of 15-20 weeks gestation and from 8 apparently healthy adult tissue transplant donors, and in liver homogenates from 2 fetuses (20 weeks gestation), 5 preterm infants (27-32 weeks gestation), and 13 term infants who survived up to 39 weeks postnatally. D1 activity was determined using $1 \mu \mathrm{M}\left[3^{\prime}, 5^{\prime}-{ }^{125} \mathrm{I}\right] \mathrm{rT}_{3}$ as substrate and $10 \mathrm{~mm}$ dithiothreitol (DTT) as cofactor, D2 activity using $1 \mathrm{~nm}\left[3^{\prime}, 5^{\prime}-{ }^{125} \mathrm{I}\right] \mathrm{T}_{4}$ and $25 \mathrm{~mm}$ DTT in the presence of $1 \mathrm{mM}$ 6-propyl-2-thiouracil (to block D1 activity) and $1 \mu \mathrm{M}$ $\mathrm{T}_{3}$ (to block D3 activity), and D3 activity using $10 \mathrm{nM}\left[3,5-{ }^{125} \mathrm{I}\right] \mathrm{T}_{3}$ and $50 \mathrm{~mm}$ DTT, by quantitation of the release of ${ }^{125} \mathrm{I}^{-}$. The assays were validated by high performance liquid chromatography of the products, and kinetic analysis [Michaelis-Menten constant $\left(\mathrm{K}_{\mathrm{m}}\right)$ of $\mathrm{rT}_{3}$ for $\mathrm{D} 1$ :
\end{abstract}

$0.5 \mu \mathrm{M} ; \mathrm{K}_{\mathrm{m}}$ of $\mathrm{T}_{3}$ for D3: $2 \mathrm{nM}$ ]. In liver homogenates, D1 activity was not correlated with age, whereas D3 activity showed a strong negative correlation with age $(\mathrm{r}-0.84)$, with high D3 activities in preterm infants and (except in 1 infant of 35 weeks) absent D3 activity in full-term infants. In microsomes, D1 activities amounted to $4.3-60$ $\mathrm{pmol} / \mathrm{min} / \mathrm{mg}$ protein in fetal livers and to $170-313 \mathrm{pmol} / \mathrm{min} / \mathrm{mg}$ protein in adult livers, whereas microsomal D3 activities were 0.15 $1.45 \mathrm{pmol} / \mathrm{min} / \mathrm{mg}$ protein in fetuses and $<0.1 \mathrm{pmol} / \mathrm{min} / \mathrm{mg}$ protein in all but one adult. In the latter sample, D3 activity amounted to 0.36 $\mathrm{pmol} / \mathrm{min} / \mathrm{mg}$ protein. D2 activity was negligible in both fetal and adult livers. These findings indicate high D1 and D3 activities in fetal human liver, and high D1 and mostly absent D3 activities in adult human liver. Therefore, the low serum $\mathrm{T}_{3}$ levels in the human fetus appear to be caused by high hepatic (and placental) D3 activity rather than caused by low hepatic D1 activity. The occasional expression of D3 in adult human liver is intriguing and deserves further investigation. (J Clin Endocrinol Metab 83: 2868-2874, 1998)
$\mathrm{T}$ HE bioactivity of thyroid hormone is regulated importantly by enzymatic deiodination in peripheral tissues (1-4). The prohormone $\mathrm{T}_{4}$ is converted by outer ring deiodination (ORD) to the active hormone $\mathrm{T}_{3}$. Both $\mathrm{T}_{4}$ and $\mathrm{T}_{3}$ are inactivated by inner ring deiodination (IRD) to $\mathrm{rT}_{3}$ and $3,3^{\prime}$ diiodothyronine $\left(3,3^{\prime}-\mathrm{T}_{2}\right)$, respectively. The latter metabolite is also produced by ORD of $\mathrm{rT}_{3}$. The three iodothyronine deiodinases involved in these processes have been characterized as homologous transmembrane selenoproteins that require thiols as cofactor (1-4). The type I deiodinase (D1) has both ORD and IRD activity. It is located in liver, kidney, and thyroid and is important for plasma $\mathrm{T}_{3}$ production. $\mathrm{rT}_{3}$ is the preferred substrate for $\mathrm{D} 1$, although the deiodination of other iodothyronines is greatly accelerated by sulfate conjugation of their 4'-hydroxyl group (1-5). D1 shows Michaelis-Menten constant $\left(\mathrm{K}_{\mathrm{m}}\right)$ values for its substrates in the micromolar range, and the enzyme is potently inhibited by 6-propyl-2-thiouracil (PTU) (1-4). The

Received January 23, 1998. Revision received April 27, 1998. Accepted May 4, 1998.

Address all correspondence and requests for reprints to: Theo J. Visser, Department of Internal Medicine III, Erasmus University Medical School, P.O. Box 1738, Room Bd. 234, 3000 DR Rotterdam, The Netherlands. E-mail: visser@inw3.azr.nl.

* This work was supported by grants from the Netherlands Organization of Scientific Research (903-40-168), Action Research, and the Wellcome Trust. type II deiodinase (D2) catalyzes only ORD of iodothyronines. D2 activity is found in brain, pituitary, and brown adipose tissue, whereas D2 messenger RNA (mRNA) has recently also been detected in human heart, skeletal muscle, and thyroid (6-8). D2 appears particularly important for local $\mathrm{T}_{3}$ production in these tissues. It shows preference for $\mathrm{T}_{4}$ over $\mathrm{rT}_{3}$ as the substrate, with $\mathrm{K}_{\mathrm{m}}$ values in the nanomolar range, and is insensitive to PTU inhibition (1-4). The type III deiodinase (D3) has only IRD activity; it is present among other tissues in brain, skin, and intestine (see also below). It shows preference for $\mathrm{T}_{3}$ over $\mathrm{T}_{4}$ as the substrate, with $\mathrm{K}_{\mathrm{m}}$ values in the nanomolar range, and is not inhibited by PTU (1-4). The expression of these enzymes is regulated by thyroid state. In general, D1 and D3 activities are increased and D2 activity is decreased in hyperthyroidism, whereas the opposite changes are observed in hypothyroidism (1-4).

The role of the deiodinases in the tissue-specific and timedependent regulation of thyroid hormone bioactivity during fetal development has been investigated in experimental animals (9-11), but little is known about the ontogeny of these enzymes in human development. In animals and humans, fetal serum $\mathrm{T}_{3}$ is low and increases only at the end of gestation and in the neonatal period (11-13). Conversely, fetal serum $\mathrm{rT}_{3}$ is high and decreases in the late fetal and early neonatal period (11-13). High levels of iodothyronine sul- 
fates, such as $T_{4} S, T_{3} S, r_{3} S$ and $3,3^{\prime}-T_{2} S$, have been documented in human and sheep fetal serum (11, 12, 14-18). Because hepatic D1 is important for production of serum $\mathrm{T}_{3}$ and for clearance of serum $\mathrm{rT}_{3}$ and iodothyronine sulfates (1-5), and because hepatic D1 activity is only expressed towards the end of fetal development, at least in rats and sheep $(9,11)$, it is generally believed that the low fetal serum $T_{3}$ and high fetal serum $\mathrm{rT}_{3}$ and sulfates reflect a low hepatic D1 activity. However, high D3 activity has been detected in human, rat, and guinea pig placenta (19-24); fetal rat brain $(25,26)$ and intestine $(27)$; and embryonic chicken liver $(28$, 29). Therefore, the low $\mathrm{T}_{3}$ and high $\mathrm{rT}_{3}$ levels in human fetal serum may also be caused by rapid degradation of serum $\mathrm{T}_{3}$ and production of serum $\mathrm{rT}_{3}$ in placenta $(23,24)$ and possibly other tissues, such as liver. The purpose of the present study was to obtain a better understanding of the ontogeny of D1 and D3 activities in human liver. The results indicate a more important role for hepatic D3 activity in the regulation of thyroid hormone bioactivity during human fetal development than previously assumed.

\section{Materials and Methods}

\section{Materials}

Nonradioactive iodothyronines were obtained from Henning Berlin (Berlin, Germany); [3,5- $\left.{ }^{125} \mathrm{I}\right] \mathrm{T}_{3}(\approx 35 \mathrm{Ci} / \mathrm{mmol})$ was obtained from $\mathrm{Dr}$. R. Thoma of Formula (Berlin, Germany) courtesy of Dr. G. Decker of Henning Berlin. $\left[3^{\prime}, 5^{\prime}-{ }^{125} \mathrm{I}\right] \mathrm{T}_{4},\left[3^{\prime}-{ }^{125} \mathrm{I}\right] \mathrm{T}_{3}$, and $\left[3^{\prime}, 5^{\prime}-125 \mathrm{I}\right] \mathrm{rT} \mathrm{r}_{3}(\approx 2000 \mathrm{Ci} /$ $\mathrm{mmol}$ ) were obtained from Amersham (Little Chalfont, UK) or prepared in our laboratory by radioiodination of $\mathrm{T}_{3}, 3,5-\mathrm{T}_{2}$, and $3,3^{\prime}-\mathrm{T}_{2}$, respectively, as described previously (30). $\left[{ }^{125} \mathrm{I}\right] \mathrm{T}_{3}$ could be used without further purification, but $\left[{ }^{125} \mathrm{I}_{\mathrm{T}}\right.$ and $\left[{ }^{125} \mathrm{I}\right] \mathrm{rT}_{3}$ were purified on Sephadex LH-20 before each experiment (30). N-bromoacetyl- $\left[3^{\prime}{ }^{\prime}{ }^{125} \mathrm{I}\right] \mathrm{T}_{3}\left(\mathrm{BrAc}\left[3^{\prime}-\right.\right.$ $\left.\left.{ }^{125} \mathrm{I}\right] \mathrm{T}_{3}\right)$ and $\mathrm{BrAc}\left[3^{\prime}, 5^{\prime}-{ }^{125} \mathrm{I}\right] \mathrm{T}_{4}$ were prepared as described previously (31). Dithiothreitol (DTT) and PTU were obtained from Sigma (St. Louis, $\mathrm{MO})$; electrophoresis grade SDS-PAGE reagents, protein markers, and protein assay reagent from Bio-Rad (Richmond, IL); Sephadex LH-20 from Pharmacia (Uppsala, Sweden); and Coomassie brilliant blue R-250 from Merck (Darmstadt, Germany).

\section{Tissues}

Liver tissue was obtained from 10 fetuses (F1-F10) of 15-20 weeks gestation as well as from 8 apparently healthy tissue transplant donors (A1-A8): 4 males (29-46 yr of age) and 4 females (34-52 yr of age). Microsomes were prepared by differential centrifugation as previously described (32), suspended in $100 \mathrm{~mm}$ phosphate ( $\mathrm{pH} 7.2$ ), and $2 \mathrm{~mm}$ EDTA (P100E2), containing $1 \mathrm{~mm}$ DTT, at a protein concentration of $\approx 10$ $\mathrm{mg} / \mathrm{ml}$. Liver tissue was also obtained at autopsy from 2 fetuses of 20 weeks gestation, 5 preterm infants of $27-32$ weeks gestation, and 13 term infants who survived up to 39 weeks postnatally. Postmortem time varied from $1-48 \mathrm{~h}$. These tissues were homogenized in $10 \mathrm{vol}$ P100E2, containing $10 \mathrm{~mm}$ DTT, yielding protein concentrations of $\approx 10 \mathrm{mg} / \mathrm{mL}$. Aliquots of microsomes and homogenates were snap-frozen on dry ice and stored at $-80 \mathrm{C}$ until further analysis. Protein concentration was determined using Bio-Rad protein assay reagent and BSA as the standard. Approval for this study was obtained from the Tayside Committee on Medical Research Ethics.

\section{Deiodinase assays}

Deiodinase activities were determined by analysis of the release of radioiodide by ORD of outer ring-labeled $\mathrm{T}_{4}$ or $\mathrm{rT}_{3}$ or by IRD of inner ring-labeled $\mathrm{T}_{3}$ during incubation for $30-60 \mathrm{~min}$ at $37 \mathrm{C}$ with liver homogenates or microsomes and DTT in $0.2 \mathrm{~mL}$ P100E2 (32). D1 activity was assayed using $1 \mu \mathrm{M}\left(10^{5} \mathrm{cpm}\right)\left[3^{\prime}, 5^{\prime}-{ }^{125} \mathrm{I}\right] \mathrm{rT}_{3}$ and $10 \mathrm{~mm}$ DTT, D2 activity using $1 \mathrm{~nm}\left(10^{5} \mathrm{cpm}\right)\left[3^{\prime}, 5^{\prime}-{ }^{125} \mathrm{ITT}_{4}\right.$ and $25 \mathrm{~mm}$ DTT in the presence of $1 \mathrm{~mm}$ PTU (to block D1 activity) and $1 \mu \mathrm{M} \mathrm{T}$ (to block D3 activity), and D3 activity using $10 \mathrm{~nm}\left(10^{5} \mathrm{cpm}\right)\left[3,5^{-125} \mathrm{I}\right] \mathrm{T}_{3}$ and $50 \mathrm{~mm}$ DTT. Reactions were stopped at $0 \mathrm{C}$ by addition of $0.1 \mathrm{~mL} 5 \%(\mathrm{wt} / \mathrm{vol})$ BSA in water followed by addition of $0.5 \mathrm{~mL} 10 \%$ (wt/vol) trichloroacetic acid in water. Precipitated ${ }^{125}$ I-labeled iodothyronines were removed by centrifugation, and the ${ }^{125} \mathrm{I}^{-}$released was further purified from the supernatant on Sephadex LH-20 microcolumns (bed volume $\approx 0.25 \mathrm{~mL}$ ), equilibrated and eluted with $0.1 \mathrm{M} \mathrm{HCl}$ (32).

The assays were validated by high performance liquid chromatography (HPLC) analysis of the deiodination products of $\mathrm{T}_{4}, \mathrm{~T}_{3}$, and $\mathrm{rT}_{3}$. For this, microsomes were incubated with a) $1 \mu \mathrm{M}\left[3^{\prime}, 5^{\prime}-{ }^{425} \mathrm{I}\right] \mathrm{rT}_{3}$ and 10 mm DTT, b) $1 \mathrm{~nm}\left[3^{\prime}, 5^{\prime}-{ }^{125} \mathrm{I}\right] \mathrm{T}_{4}$ and $25 \mathrm{~mm}$ DTT in the absence or presence of $1 \mathrm{~mm}$ PTU and/or $1 \mu \mathrm{M} \mathrm{T}$, or c) $10 \mathrm{~nm}\left[3,5^{-125} \mathrm{ITT}_{3}\right.$ and $50 \mathrm{~mm}$ DTT in $0.2 \mathrm{~mL}$ P100E2. The reactions were stopped by addition of $0.2 \mathrm{~mL}$ ice-cold methanol. After centrifugation, $0.2 \mathrm{~mL}$ of the supernatant was mixed with $0.3 \mathrm{~mL} 0.02 \mathrm{M}$ ammonium acetate $(\mathrm{pH} 4)$, and $0.1 \mathrm{~mL}$ of the mixture was applied to a $250 \times 4.6 \mathrm{~mm}$ Symmetry C18 column (Waters, Etten-Leur, The Netherlands) connected to an Alliance HPLC system (Waters) and eluted isocratically with a mixture of acetonitrile and 0.02 $\mathrm{M}$ ammonium acetate $(33: 67, \mathrm{vol} / \mathrm{vol})$ at a flow of $1.2 \mathrm{~mL} / \mathrm{min}$. Fractions of $0.3 \mathrm{~min}$ were collected and counted for radioactivity.

\section{Affinity labeling}

$\mathrm{BrAc}\left[{ }^{125} \mathrm{I}\right] \mathrm{T}_{3}$ or $\mathrm{BrAc}^{125} \mathrm{I}^{\mathrm{T}} \mathrm{T}_{4}(0.1 \mu \mathrm{Ci})$ was reacted for $20 \mathrm{~min}$ at $37 \mathrm{C}$ with $0.1 \mathrm{mg}$ microsomal protein in $0.1 \mathrm{~mL}$ P100E2 containing $1 \mathrm{~mm}$ DTT (30). The reaction was stopped by addition of $50 \mu \mathrm{L}$ SDS-sample buffer containing 30\% $\beta$-mercaptoethanol and treatment for $5 \mathrm{~min}$ at $100 \mathrm{C}$. Proteins were separated overnight by SDS-PAGE in a $16-\mathrm{cm} 10 \%$ polyacrylamide gel. Gels were stained with Coomassie brilliant blue R-250 at $60 \mathrm{C}$, dried at $80 \mathrm{C}$ under vacuum, and autoradiographed at $-70 \mathrm{C}$ using Fuji RX film (Fuji Medical Systems, Houten, The Netherlands). Apparent molecular mass $\left(\mathrm{M}_{\mathrm{r}}\right)$ was determined by interpolation with protein markers.

\section{Results}

Deiodinase activities were determined in liver homogenates from 2 fetuses of 20 weeks gestation, 5 preterm infants of 27-32 weeks gestation who died soon after birth, and 13 term infants who survived up to 39 weeks postnatally. Causes of death included congenital defects, infection, metabolic storage disease, sudden death, and prematurity. The tissues were obtained at autopsy with a postmortem time of 1-48 h. Figure 1A shows the D1 activities of these liver homogenates as a function of gestational/postnatal age. Considering the varying conditions of the tissues, the appreciable scatter of the data was not surprising. However, it is clear that hepatic D1 activity demonstrated little or no dependence on age in the range studied, with activities at 20 weeks gestation being very similar to those observed after 20 weeks postnatally. D1 activity was not correlated with postmortem time (not shown). Figure 1B shows the hepatic D3 activities in these same tissue homogenates as a function of age. In spite of the considerable scatter, there was clearly a decrease in hepatic D3 activity with age. In general, high D3 activities were observed during fetal development, which virtually disappeared after birth in term infants. Hepatic D3 activity was unexpectedly low for age in 1 infant born at 27 weeks gestation who died from intrauterine infection. Interestingly, D3 activity was unexpectedly high for age in a term infant with GM1 gangliosidosis who died at 35 weeks of age from pneumonia. Hepatic D3 activity was not correlated with postmortem time (data not shown). D2 activities in these liver homogenates were negligible (data not shown).

Figure 2 shows the microsomal D1 and D3 activities in five representative fetal liver samples obtained at 15-20 weeks 
A

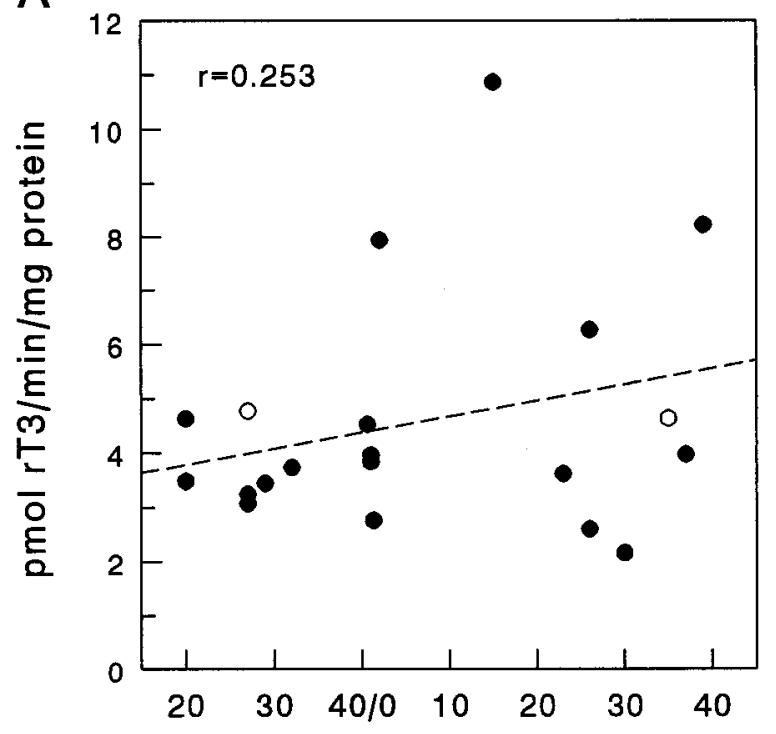

gestational/postnatal age (wks)

B

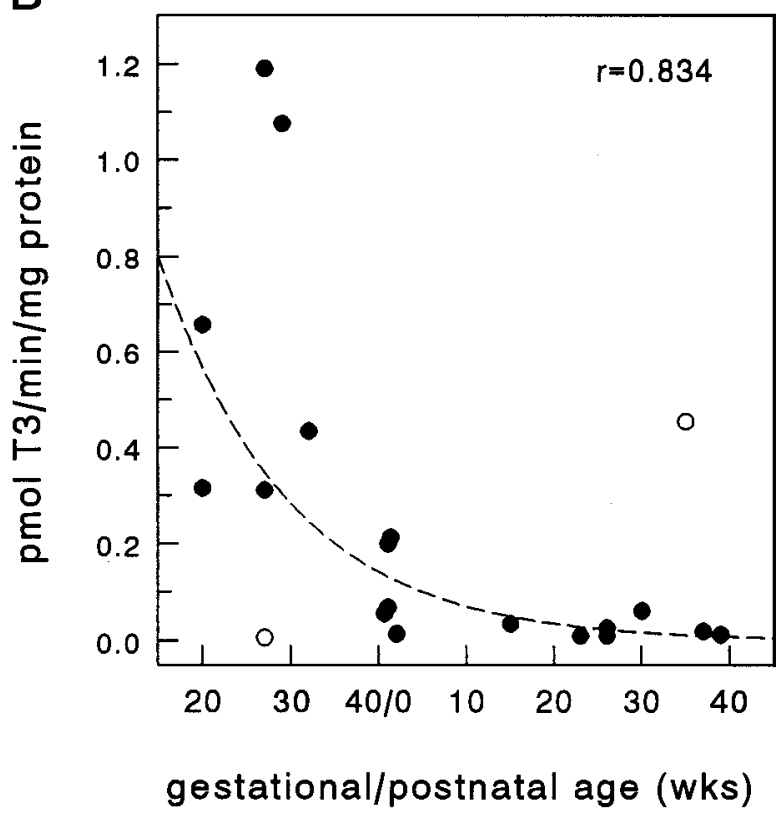

Fig. 1. D1 (A) and D3 (B) activities in human liver homogenates as function of gestational/postnatal age. Reaction conditions: $1 \mu \mathrm{M}\left[3^{\prime}, 5^{\prime}-\right.$ $\left.{ }^{125} \mathrm{I}\right] \mathrm{rT}_{3}$ and $10 \mathrm{~mm}$ DTT (A) or $10 \mathrm{~nm}\left[3,5-{ }^{125} \mathrm{I}\right] \mathrm{T}_{3}$ and $50 \mathrm{~mm} \mathrm{DTT} \mathrm{(B),}$ $0.25 \mathrm{mg}$ protein $/ \mathrm{mL}$, and $30 \mathrm{~min}$ incubation. $\bigcirc$, Outliers with strongly deviating D3 activities.

gestation as well as in five representative adult liver samples. Again, there was considerable scatter in both D1 and D3 activities in the fetal samples. There was no significant relationship of either D1 or D3 activity with fetal age (data not shown). However, D1 and D3 activities were significantly correlated ( $r=0.85$; data not shown), suggesting that the variation in both deiodinase activities was related to the quality of the tissues. Hepatic D1 activity in the adult tissue transplant donors showed a relatively narrow range of vari-

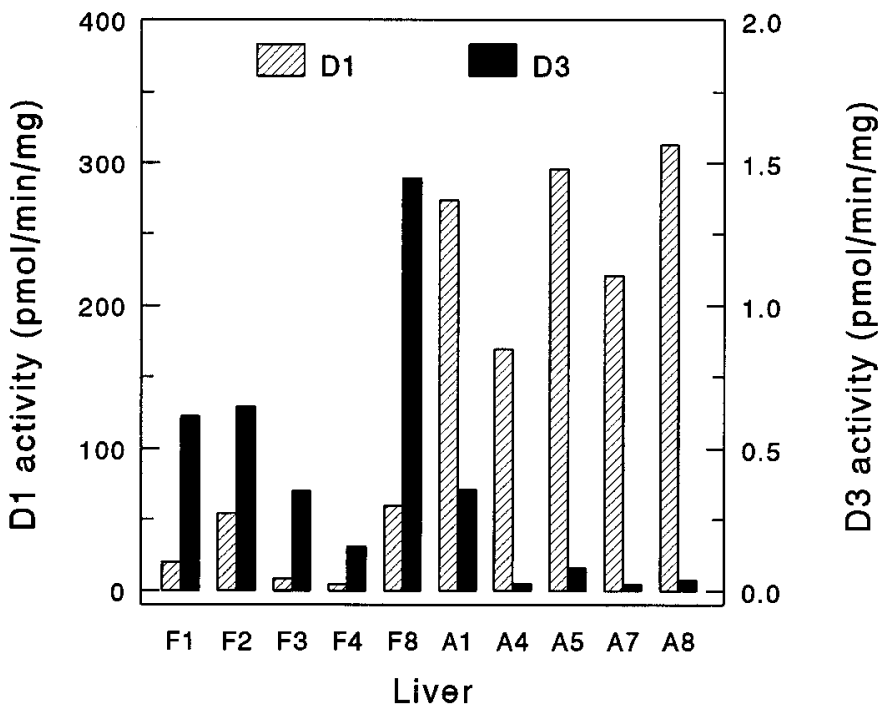

FIG. 2. Microsomal D1 and D3 activities in representative fetal (F) or adult (A) livers. Reaction conditions: D1, $1 \mu \mathrm{M}\left[3^{\prime}, 5^{\prime}{ }^{125} \mathrm{I}\right] \mathrm{rT}_{3}, 10 \mathrm{mM}$ DTT, and $50 \mu \mathrm{g}$ (F) or $25 \mu \mathrm{g}$ (A) protein/mL. D3, $10 \mathrm{~nm}\left[3,5-{ }^{125} \mathrm{I}\right] \mathrm{T}_{3}$, $50 \mathrm{~mm}$ DTT, and $50 \mu \mathrm{g}$ (F) or $250 \mu \mathrm{g}$ (A) protein $/ \mathrm{mL}$. Incubation time was $30 \mathrm{~min}$.

ation. D1 activity in fetal liver amounted up to $24 \%$ of that in adult liver. In seven of the eight adult liver samples D3 activity was very low (Fig. 2 and data not shown). However, significant hepatic D3 activity was detected in the remaining adult tissue sample (A1), which amounted to $56 \%$ of the mean fetal hepatic D3 activity. D2 activity was negligible in both fetal and adult liver (data not shown).

The different deiodinase assays were validated by HPLC analysis. The results demonstrated equivalent production of radiolabeled iodide and $3,3^{\prime}-\mathrm{T}_{2}$ from $\left[3^{\prime}, 5^{\prime}{ }^{125} \mathrm{I}\right] \mathrm{rT}$ in the D1 assay as well as from $\left[3,5-{ }^{125} \mathrm{I}\right] \mathrm{T}_{3}$ in the D3 assay (data not shown). Deiodination of $\left[3^{\prime}, 5^{\prime}-{ }^{125} \mathrm{ITT}_{4}\right.$ by fetal liver microsomes in the absence of PTU or unlabeled $\mathrm{T}_{3}$ resulted in the formation of radioactive $\mathrm{rT}_{3}, 3,3^{\prime}-\mathrm{T}_{2}$, and iodide, suggesting IRD of $\mathrm{T}_{4}$ by $\mathrm{D} 3$ to $\mathrm{rT}_{3}$ and subsequent ORD of $\mathrm{rT}_{3}$ by $\mathrm{D} 1$ to $3,3^{\prime}-\mathrm{T}_{2}$ and iodide (Fig. 3A). Some labeled $3^{\prime}-\mathrm{T} 1$ was also produced presumably by IRD of $3,3^{\prime}-\mathrm{T}_{2}$ by D3. Addition of PTU did not affect the IRD of $\mathrm{T}_{4}$ but partially inhibited the further ORD of $\mathrm{rT}_{3}$ (Fig. 3B). In the presence of $1 \mu \mathrm{M}$ unlabeled $\mathrm{T}_{3}$, conversion of $\left[{ }^{125} \mathrm{I}\right] \mathrm{T}_{4}$ to $\left[{ }^{125} \mathrm{I}\right] \mathrm{rT}_{3}$ was completely inhibited, and a very small amount of $\left[{ }^{125} \mathrm{I}\right] \mathrm{T}_{3}$ was found to accumulate, apparently caused by inhibition of its degradation by D3 (Fig. 3C). Addition of both PTU and unlabeled $\mathrm{T}_{3}$ resulted in the complete inhibition of $\mathrm{T}_{4}$ metabolism (Fig. 3D).

Figure 4 shows the double-reciprocal plots of the deiodination rates of $\mathrm{rT}_{3}$ and $\mathrm{T}_{3}$ by fetal and adult liver microsomes as a function of substrate concentration. Although the maximum velocity $\left(\mathrm{V}_{\text {max }}\right)$ value for $\mathrm{rT}_{3}$ deiodination estimated from these plots was higher in adult than in fetal liver, the apparent $\mathrm{K}_{\mathrm{m}}$ value for $\mathrm{rT}_{3}$ amounted to $0.5 \mu \mathrm{M}$ with both representative tissue samples (Fig. 4A). The deiodination of $\mathrm{rT}_{3}$ was completely inhibited by $1 \mathrm{~mm}$ PTU in both fetal and adult liver (not shown). The deiodination of $\mathrm{T}_{3}$ by a representative fetal liver sample and by adult liver sample A1 was characterized by very similar $\mathrm{Km}$ values, i.e. 1.4 and $2.5 \mathrm{~nm}$, 
A

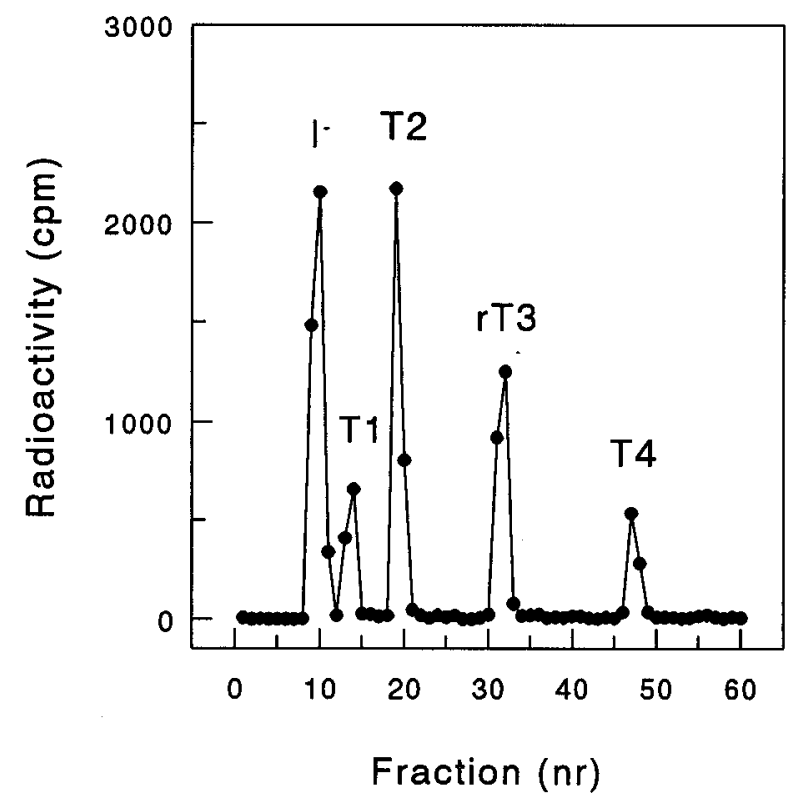

B

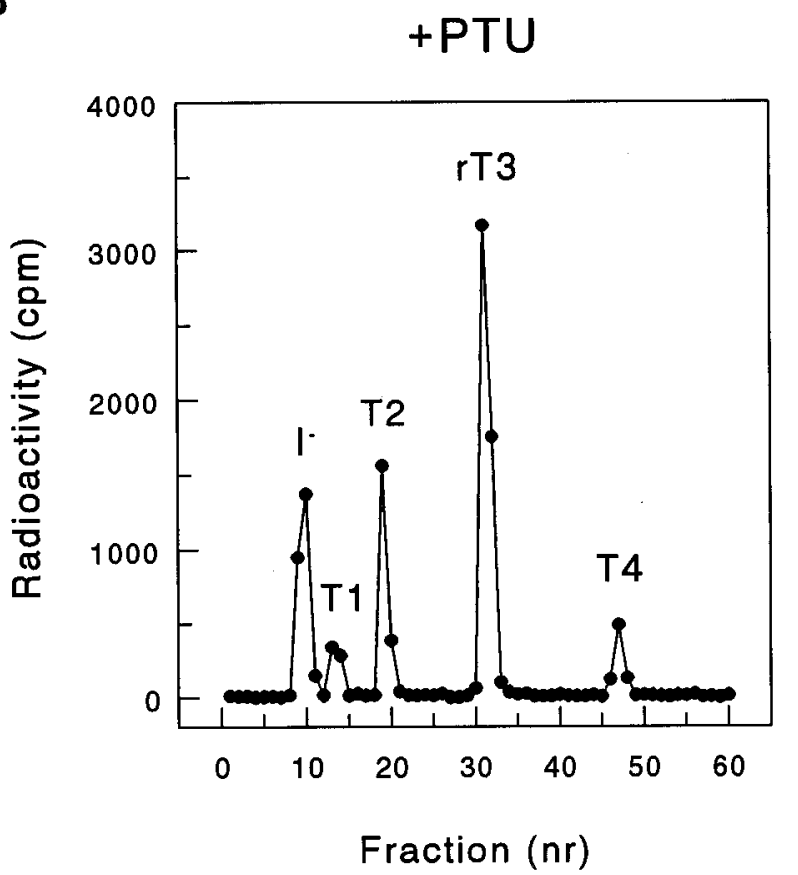

C
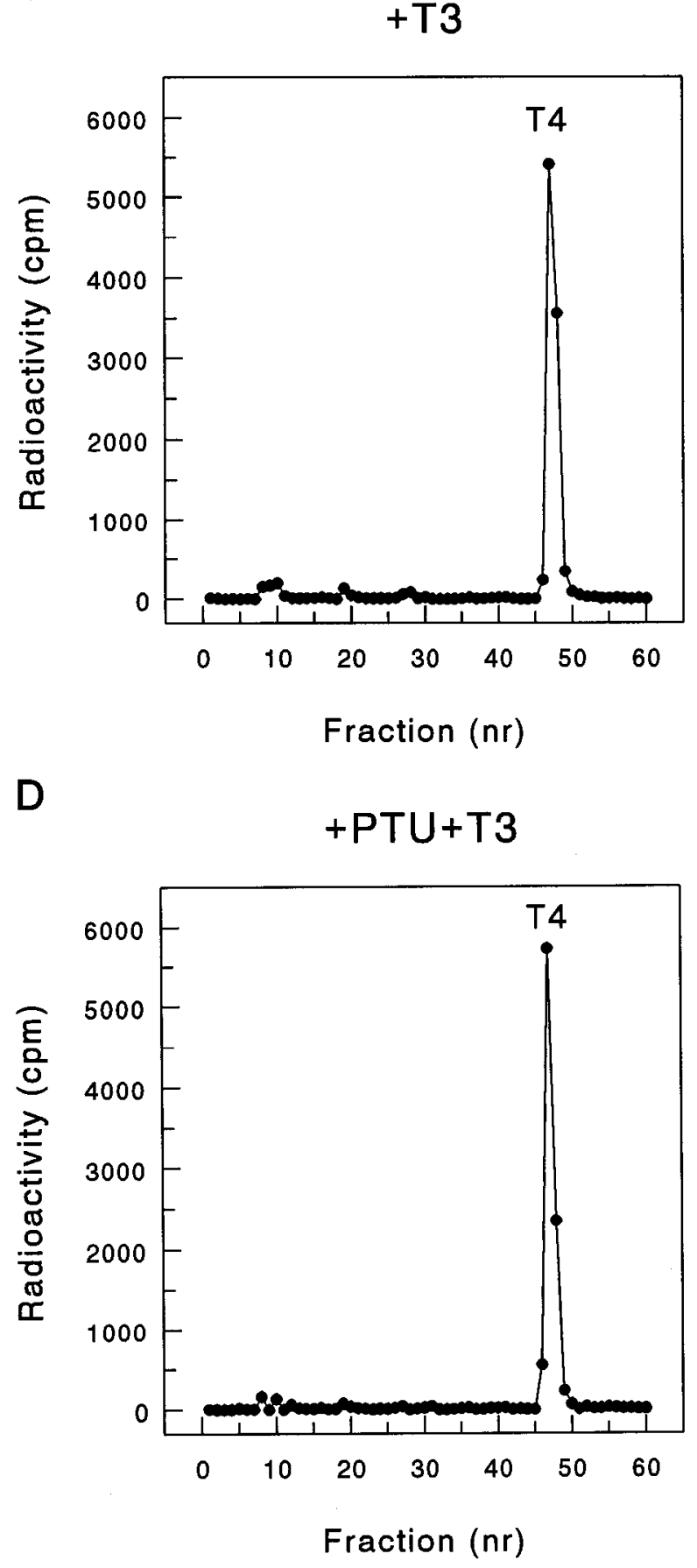

FIG. 3. HPLC analysis of deiodination products of $\mathrm{T}_{4}$ formed during incubation with fetal human liver microsomes and DTT in absence or presence of PTU and/or unlabeled $\mathrm{T}_{3}$. Reaction conditions: $1 \mathrm{~nm}\left[3^{\prime}, 5^{\prime}{ }_{-}{ }^{125} \mathrm{I}\right] \mathrm{T}_{4}, 25 \mathrm{~mm}$ DTT and $250 \mu \mathrm{g}$ protein/mL, without PTU or $\mathrm{T}_{3}(\mathrm{~A})$, with $1 \mathrm{~mm}$ PTU (B), with $1 \mu \mathrm{M} \mathrm{T} \mathrm{T}_{3}(\mathrm{C})$, or with $1 \mathrm{~mm}$ PTU and $1 \mu \mathrm{M} \mathrm{T} \mathrm{T}_{3}$ (D). Incubation time was 30 min. Extraction and HPLC analysis was done as described in Materials and Methods.

respectively (Fig. 4B). In both cases, deiodination of $\mathrm{T}_{3}$ was not affected by the addition of $1 \mathrm{~mm}$ PTU (not shown).

Figure 5 shows the results of the affinity labeling of fetal and adult human liver microsomal proteins by $\mathrm{BrAc}\left[{ }^{125} \mathrm{I}_{4}\right.$ or $\mathrm{BrAc}\left[{ }^{125} \mathrm{I}_{3}\right.$. As demonstrated previously (30), the radioactive band of $\approx 27 \mathrm{kDa}$ represents the affinity labeling of D1. These findings, therefore, suggest similar levels of D1 protein in fetal and adult human liver. No evidence was obtained for affinity labeling of $\mathrm{D} 3$ with either $\mathrm{BrAc}\left[{ }^{125} \mathrm{I}\right] \mathrm{T}_{3}$ or $\mathrm{BrAc}\left[{ }^{125} \mathrm{I}_{\mathrm{T}}\right.$, which is in agreement with our previous failure to identify D3 in rat placenta and embryonic chicken liver using these affinity labels (33).

Northern analysis of RNA isolated from two fetal and two adult human liver samples using human D1 and D3 com- 
A

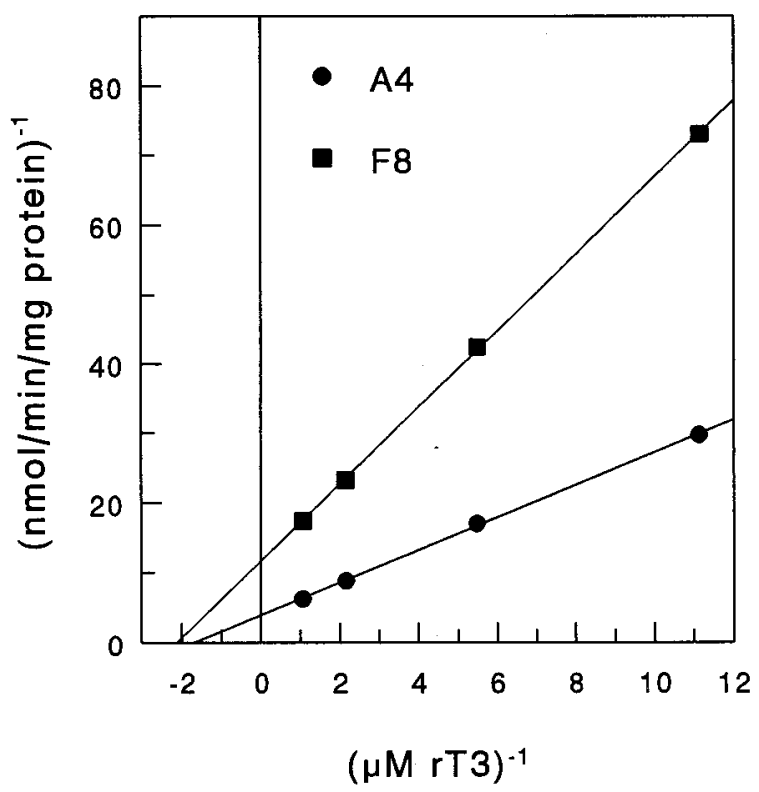

B

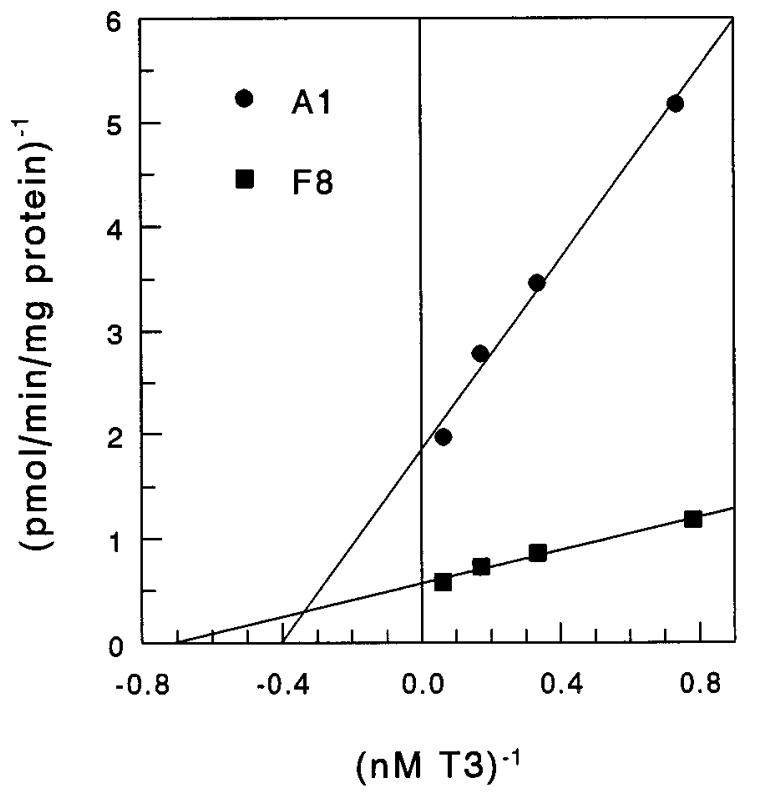

FIG. 4. Double-reciprocal plots of deiodination of $\mathrm{rT}_{3}(\mathrm{~A})$ or $\mathrm{T}_{3}(\mathrm{~B})$ by fetal (F8) or adult (A1 and A4) human liver microsomes as function of substrate concentration. Reaction conditions: A, 0.1-1 $\mu \mathrm{M}\left[3^{\prime}, 5^{\prime}-\right.$ ${ }^{125} \mathrm{I}_{\mathrm{rT}}, 10 \mathrm{~mm} \mathrm{DTT}$, and $50 \mu \mathrm{g}(\mathrm{F} 8)$ or $20 \mu \mathrm{g}$ (A4) protein $/ \mathrm{mL}$; B, $1.5-15 \mathrm{~nm}\left[3,5^{-125} \mathrm{I}\right] \mathrm{T}_{3}, 50 \mathrm{~mm}$ DTT, and $25 \mu \mathrm{g}$ (F8) or $100 \mu \mathrm{g}$ (A1) protein/mL. Incubation time was $30 \mathrm{~min}$.

plementary DNA probes indicated extensive degradation of RNA and suggested expression of both D1 and D3 mRNA in fetal liver and expression of only D1 mRNA in adult liver (data not shown).

\section{Discussion}

Thyroid hormone bioavalability in the human fetus is dependent on, among other things, a) supply of maternal hormone through the placenta, b) hormone production by the

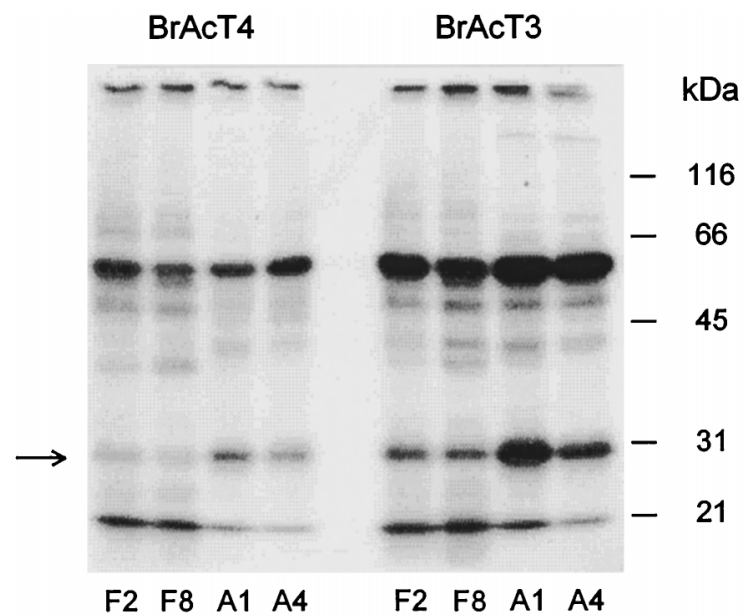

Fig. 5. Affinity labeling of fetal and adult liver microsomal proteins with $\mathrm{BrAc}\left[{ }^{125} \mathrm{I}\right] \mathrm{T}_{4}$ or $\mathrm{BrAc}\left[{ }^{125} \mathrm{I}\right] \mathrm{T}_{3}$. Position of marker proteins and their $\mathrm{M}_{\mathrm{r}}$ values as well as labeled D1 protein (arrow) are indicated. Reaction conditions: $0.1 \mu \mathrm{Ci} \mathrm{BrAc}\left[{ }^{125} \mathrm{I}\right] \mathrm{T}_{4}$ or $\mathrm{BrAc}\left[{ }^{125} \mathrm{I}\right] \mathrm{T}_{3}, 0.1 \mathrm{mg}$ protein, $1 \mathrm{~mm}$ DTT in $0.1 \mathrm{~mL}$ P100E2, and $20 \mathrm{~min}$ incubation. Electrophoresis and autoradiography were done as described in Materials and Methods.

fetal thyroid gland, c) the activities of thyroid hormonemetabolizing enzymes such as deiodinases and sulfotransferases in fetal tissues, d) the activities of plasma membrane transporters that mediate uptake of iodothyronines from serum into the tissues, e) exchange (uptake and excretion) of hormone with the amniotic fluid, and f) return of fetal hormone via the placenta to the mother (11-13).

$\mathrm{T}_{4}$ production by the human fetal thyroid gland has been demonstrated after 10-12 weeks of gestation (11-13). Before this period all $\mathrm{T}_{4}$ in the fetal circulation is derived from maternal supply across the placenta. However, maternal supply probably remains an important source of fetal thyroid hormone after development of the fetal thyroid gland, as evidenced by substantial $\mathrm{T}_{4}$ levels in newborns with thyroid agenesis or a complete hormone synthesis defect (34). In view of the available $\mathrm{T}_{4}$ levels, serum $\mathrm{T}_{3}$ is low and serum $\mathrm{rT}_{3}$ is high in the human fetus, in particular during the first two trimesters $(11-13,35)$. This can be explained by the welldocumented high D3 activity in the placenta, which presumably converts a large proportion of $\mathrm{T}_{4}$ to $\mathrm{rT}_{3}$ and of $\mathrm{T}_{3}$ to $3,3^{\prime}-\mathrm{T}_{2}$ during placental transfer (19-24). In addition, findings of high D3 activities in fetal rat brain (25-27) and intestine (27) and in embryonic chicken liver $(28,29)$ have suggested that significant D3 activity may also be expressed in fetal human tissues. Furthermore, in analogy with the ontogeny of D1 expression in rat liver $(9,27)$, it has been generally assumed that hepatic $\mathrm{T}_{3}$ production and $\mathrm{rT}_{3}$ clearance remain low until D1 starts to be expressed towards the end of human fetal development. This is supported by the high levels of $T_{4} S, T_{3} S, r_{3} S$, and $3,3^{\prime}-T_{2} S$ in human fetal serum (14-18), because these conjugates are cleared importantly by hepatic D1 (5).

Because very little is known about the potential role of hepatic D1 and D3 in the regulation of thyroid hormone bioactivity during human fetal development, we carried out the present study. Although the autopsy samples were ob- 
tained from sick infants, and the condition of the tissues, when they were collected, was in some cases suboptimal, the results clearly indicate that D1 activity already is expressed in the second trimester at levels similar to those observed in infants who survived up to 39 weeks postnatally. Another remarkable finding was the high D3 activity in liver homogenates from preterm infants, which was not detectable in livers from term born infants with one exception (see below). These findings were confirmed by comparing microsomal deiodinase activities in fetal livers of 15-20 weeks gestation with those determined in liver samples from apparently healthy adult tissue, showing that D1 activity in fetal liver amounted to at least $20 \%$ of that in adult liver. Furthermore, in contrast to the high D3 activities in fetal liver, D3 activity was absent in adult liver with one exception (see below). These findings strongly suggest that the low serum $\mathrm{T}_{3}$ and high serum $\mathrm{rT}_{3}$ levels in the human fetus are not so much caused by low hepatic D1 activity but rather to high D3 activity in the liver in addition to the placenta and possibly other tissues. The relative importance of the D3 activity in the fetal liver vs. that in the placenta is difficult to assess. The specific activity of the enzyme is similar in these tissues, but because of the difference in tissue weight, the total amount of enzyme is larger in placenta than in fetal liver.

The expression of hepatic D1 and D3 activities during human fetal development is remarkably different from that in rats $(9,27)$ but resembles the ontogeny of these enzymes in the chicken liver $(28,29,36)$. In the chicken, hepatic D1 activity and mRNA level gradually increase until the end (day 20) of embryonic development (E20) $(29,36)$. In contrast, hepatic D3 activity and mRNA level strongly increase until E17, which is followed by a steep decline after E18 to almost undetectable levels at internal pipping on E20 $(29,36)$. This fall in hepatic D3 activity is associated with a dramatic increase in serum $T_{3}$ levels, suggesting that serum $T_{3}$ in the chicken embryo is determined to an important extent through regulation of its degradation by hepatic D3 activity $(29,36)$. It has been demonstrated that GH plays an essential role in the down-regulation of D3 expression in chicken liver at the end of embryonic development (37). Interestingly, Darras et al. (38) have also shown an acute and profound decrease in hepatic D3 activity after administration of dexamethasone to E18 chicken embryos. This was accompanied by a marked increase in serum $\mathrm{T}_{3}$ and a marked decrease in serum $\mathrm{rT}_{3}$ (38). It is tempting to speculate that part of the beneficial effect of the antenatal administration of glucocorticosteroids to mothers in case of an imminent premature delivery on the postnatal development of the infant (39) is caused by this down-regulation of hepatic D3 activity and consequent increase in serum $\mathrm{T}_{3}$ levels.

It is generally believed that the high D3 activity in placenta, fetal liver, and possibly other fetal tissues protects the fetus during critical stages of development against active thyroid hormone $(11-13,23)$. D3 is an important enzyme for the irreversible degradation of thyroid hormone, because the products generated from $\mathrm{T}_{4}$ and $\mathrm{T}_{3}$ by this enzyme, i.e. $\mathrm{rT}_{3}$ and $3,3^{\prime}-\mathrm{T}_{2}$, have very little affinity for the nuclear $\mathrm{T}_{3}$ receptor (TR) nor can they be converted to TR-binding ligands (40). $\mathrm{T}_{3}$ stimulates the differentiation of cells, and premature exposure of growing tissues to active hormone may thus result in congenital abnormalities. Sulfation is another pathway by which thyroid hormone is inactivated, because $T_{3} S$ has lost its affinity for TR (41). Furthermore, in adult subjects, sulfation represents the first step in a pathway leading to the irreversible degradation of thyroid hormone, because IRD of $\mathrm{T}_{4} \mathrm{~S}$ and $\mathrm{T}_{3} \mathrm{~S}$ by D1 is greatly accelerated compared with the deiodination of the nonsulfated iodothyronines (5). The importance of D1 for the clearance of serum $T_{4} S, T_{3} S, r T_{3} S$, and $3,3^{\prime}-\mathrm{T}_{2} \mathrm{~S}$ is indicated by the marked increases in the serum levels of these conjugates after inhibition of D1 by PTU and, in particular, iopanoic acid $(14,42-44)$. The high levels of the iodothyronine sulfates in human fetal serum have also been explained by the reduced clearance of these conjugates presumably caused by low hepatic D1 expression, although evidence has also been reported that production of the sulfates is increased in fetal sheep $(11,45)$. It has been speculated that $T_{3} S$ represents a reservoir of inactive hormone from which active $T_{3}$ may be released by sulfatases expressed in different tissues $(5,46)$. Our results show that hepatic D1 activity may be somewhat lower in the human fetus than in the adult but not to the extent that would explain the strongly increased $T_{4} S, T_{3} S, r T_{3} S$, and 3,3'- $T_{2} S$ levels in fetal serum. This suggests that additional mechanisms contribute to the elevation of serum iodothyronine sulfate levels in human fetal serum, such as decreased expression of plasma membrane transporters involved in tissue uptake of these conjugates (3).

Another surprising finding of our study is the occasional expression of hepatic D3 in livers from older subjects. If this represents a defect in the mechanism that normally shuts off D3 gene expression in the liver after birth or, more likely, reexpression of the gene under pathological conditions, remains to be explored. In this respect, it should be mentioned that high D3 activity has been detected in a monkey hepatocarcinoma cell line (47). It is also tempting to speculate that, like other fetoproteins, hepatic D3 expression may be stimulated by cytokines (48). If this is the case, changes in peripheral thyroid hormone metabolism in the low $\mathrm{T}_{3}$ syndrome associated with nonthyroidal illness (49) may include up-regulation of hepatic D3 activity.

D2 activity was undectable in both fetal and adult human liver samples. We cannot exclude, however, that D2 activity may be expressed in human fetal liver but is lost caused by postmortem inactivation (50).

In conclusion, we have shown that expression of both D1 and D3 in human fetal liver is higher than previously assumed. This suggests that the low $\mathrm{T}_{3}$ and high $\mathrm{rT}_{3}$ levels in human fetal serum is not so much caused by low hepatic D1 expression but rather to high D3 activity in fetal human liver in addition to placenta and perhaps other fetal tissues. The exact role of D3 expression in the tissue-specific and stagedependent regulation of thyroid hormone bioactivity during human fetal development remains to be fully investigated.

\section{References}

1. Larsen PR, Berry MJ. 1995 Nutritional and hormonal regulation of thyroid hormone deiodinases. Annu Rev Nutr. 15:323-352.

2. Leonard JL, Köhrle J. 1996 Intracellular pathways of iodothyronine metabolism. In: Braverman LE, Utiger RD, eds. The thyroid. Philadelphia: LippincottRaven; $144-189$

3. Hennemann G, Visser TJ. 1997 Thyroid hormone synthesis, plasma mem- 
brane transport and metabolism. In: Weetman AP, Grossman A, eds. Handbook of experimental pharmacology, Vol 128: Pharmacotherapeutics of the thyroid gland. New York: Springer-Verlag; 75-117.

4. St.Germain DL, Galton VA. 1997 The deiodinase family of selenoproteins. Thyroid. 7:655-668

5. Visser TJ. 1994 Role of sulfation in thyroid hormone metabolism. Chem Biol Interact. 92:293-303.

6. Croteau W, Davey JC, Galton VA, St.Germain DL. 1996 Cloning of the mammalian type II iodothyronine deiodinase: a selenoprotein differentially expressed and regulated in human and rat brain and other tissues. J Clin Invest. 98:405-417.

7. Salvatore D, Bartha T, Harney JW, Larsen PR. 1996 Molecular biological and biochemical characterization of the human type 2 selenodeiodinase. Endocrinology. 137:3308-3315.

8. Salvatore D, Tu H, Harney JW, Larsen PR. 1996 Type 2 iodothyronine deiodinase is highly expressed in human thyroid. J Clin Invest. 98:962-968.

9. De Oña CR, Morreale de Escobar G, Calvo R, Escobar del Rey F, Obregón MJ. 1991 Thyroid hormones and 5'-deiodinase in the rat fetus late in gestation: effects of maternal hypothyroidism. Endocrinology. 128:422-432.

10. Han DC, Sato K, Fujii Y, et al. 1988 3,3',5'-Triiodothyronine inhibits ontogenetic development of iodothyronine-5'-deiodinase in the liver of the neonatal mouse. Acta Endocrinol (Copenh). 119:181-188.

11. Polk DH. 1995 Thyroid hormone metabolism during development. Reprod Fertil Dev. 7:469-477.

12. Burrow GN, Fisher DA, Larsen PR. 1994 Maternal and fetal thyroid function. N Eng J Med. 331:1072-1078.

13. Thorpe-Beeston JG, Nicolaides KH, McGregor AM. 1992 Fetal thyroid function. Thyroid. 2:207-217.

14. Chopra IJ, Wu SY, Chua Teco GN, Santini F. 1992 A radioimmunoassay of 3,5,3'-triiodothyronine sulfate: studies in thyroidal and nonthyroidal diseases, pregnancy, and neonatal life. J Clin Endocrinol Metab. 75:189-194.

15. Wu SY, Huang WS, Polk D, Florsheim WH, Green WL, Fisher DA. 1992 Identification of thyroxine sulfate (T4S) in human serum and amniotic fluid by a novel T4S radioimmunoassay. Thyroid. 2:101-105.

16. Wu SY, Huang WS, Polk D, et al. 1993 The development of a radioimmunoassay for reverse triiodothyronine sulfate in human serum and amniotic fluid. J Clin Endocrinol Metab. 76:1625-1630.

17. Wu SY, Polk DH, Chen WL, Fisher DA, Huang WS, Yee B. 1994 A 3,3'diiodothyronine sulfate cross-reactive compound in serum from pregnant women. J Clin Endocrinol Metab. 78:1505-1509.

18. Santini F, Cortelazzi D, Baggiani AM, Marconi AM, Beck-Peccoz P, Chopra IJ. 1993 A study of the serum 3,5,3'-triiodothyronine sulfate concentration in normal and hypothyroid fetuses at various gestational stages. J Clin Endocrinol Metab. 76:1583-1587.

19. Roti E, Gnudi A, Braverman LE. 1983 The placental transport, synthesis and metabolism of hormones and drugs which affect thyroid function. Endocr Rev. 4:131-149.

20. Koopdonk-Kool JM, de Vijlder JJM, Veenboer GJM, et al. 1996 Type II and type III deiodinase activity in human placenta as function of gestational age. J Clin Endocrinol Metab. 81:2154-2158.

21. Cooper E, Gibbens M, Thomas CR, Lowy C, Burke CW. 1983 Conversion of thyroxine to $3,3^{\prime}, 5^{\prime}$-triiodothyronine in the guinea pig placenta: in vivo studies. Endocrinology. 112:1808-1815.

22. Castro MI, Braverman LE, Alex S, Wu CF, Emerson CH. 1985 Inner-ring deiodination of $3,5,3^{\prime}$-triiodothyronine in the in situ perfused guinea pig placenta. J Clin Invest. 76:1921-1926.

23. Emerson $\mathbf{C H}$, Braverman LE. 1984 Peripheral deiodination of thyroid hormones in placenta and fetal membranes. Hormone Metab Res Suppl. 14:56-62.

24. Emerson CH, Braverman LE. 1991 Transfer and metabolism of thyroid-related substances in the placenta. Adv Exp Med Biol. 299:181-196.

25. Kaplan MM, Yaskosky KA. 1981 Maturational patterns of iodothyronine phenolic and tyrosyl ring deiodinase activities in rat cerebrum, cerebellum, and hypopthalamus. J Clin Invest. 67:1208-1214.

26. Huang TS, Chopra IJ, Boado R, Solomon DH, Chua Teco GN. 1988 Thyroxine inner ring monodeiodinating activity in fetal tissues of the rat. Pediat Res. 23:196-199.

27. Galton VA, McCarthy PT, St.Germain DL. 1991 The ontogeny of iodothyronine deiodinase systems in the liver and intestine of the rat. Endocrinology. 128:1717-1722.
28. Borges M, Labourene J, Ingbar SH. 1980 Changes in hepatic iodothyronine metabolism during ontogeny of the chick embryo. Endocrinology. 107:1751-1761.

29. Darras VM, Visser TJ, Berghman LR, Kühn ER. 1992 Ontogeny of type I and type III deiodinase activities in embryonic and posthatch chicks: relationship with changes in plasma triiodothyronine and growth hormone levels. Comp Biochem Physiol. 103A:131-136.

30. Schoenmakers CHH, Pigmans IGAJ, Visser TJ. 1992 Species differences in liver type I iodothyronine deiodinase. Biochim Biophys Acta. 1121:160-166.

31. Toyoda N, Kaptein E, Berry MJ, Harney JW, Larsen PR, Visser TJ. 1997 Structure-activity relationships for thyroid hormone deiodination by mammalian type I iodothyronine deiodinases. Endocrinology. 138:213-219.

32. Visser TJ, Kaptein E, Terpstra OT, Krenning EP. 1988 Deiodination of thyroid hormone by human liver. J Clin Endocrinol Metab. 67:17-24.

33. Schoenmakers CHH, Pigmans IGAJ, Visser TJ. 1995 Investigation of type I and type III iodothyronine deiodinases in rat tissues using N-bromoacetyliodothyronine affinity-labels. Mol Cell Endocrinol. 107:173-180.

34. Vulsma T, Gons MH, De Vijlder JJM. 1989 Maternal-fetal transfer of thyroxine in congenital hypothyroidism due to a total organification defect or thyroid agenesis. N Eng J Med. 321:13-16.

35. Thorpe-Beeston JG, Nicolaides KH, Felto CV, Butler J, McGregor AM. 1991 Maturation of the secretion of thyroid hormone and thyroid-stimulating hormone in the fetus. N Eng J Med. 324:532-536.

36. Van der Geyten S, Sanders JP, Kaptein E, et al. 1997 Hepatic expression of chicken type I and III iodothyronine deiodinase during embryonic development. Endocrinology. 138:5144-5152.

37. Darras VM, Berghman LR, Vanderpooten A, Kühn ER. 1992 Growth hormone acutely decreases type III iodothyronine deiodinase in chicken liver. FEBS Lett. 310:5-8.

38. Darras VM, Kotanen SP, Geris KL, Berghman LR, Kühn ER. 1996 Plasma thyroid hormone levels and iodothyronine deiodinase activity following an acute glucocorticoid challenge in embryonic compared with posthatch chickens. Gen Comp Endocrinol. 104:203-212.

39. Crowley P, Chalmers I, Keirse MIN. 1976 The effect of corticosteroid administration before preterm delivery: an overview of the evidence from controlled trials. Br J Obstet Gynaecol. 97:11-25.

40. Oppenheimer JH, Schwartz HL, Strait KA. 1996 The molecular basis of thyroid hormone actions. In: Braverman LE, Utiger RD, eds. The thyroid. Philadelphia: Lippincott-Raven; 162-184.

41. Spaulding SW. 1994 Bioactivities of conjugated iodothyronines. In: Wu SY, Visser TJ, eds. Thyroid hormone metabolism: molecular biology and alternate pathways. Boca Raton, FL, CRC Press; 139-153.

42. Rutgers M, Bonthuis F, De Herder WW, Visser TJ. 1987 Accumulation of plasma triiodothyronine sulfate in rats treated with propylthiouracil. J Clin Invest. 80:758-762.

43. Eelkman Rooda SJ, Kaptein E, Rutgers M, Visser TJ. 1989 Increased plasma 3,5, '3'-triiodothyronine sulfate in rats with inhibited type I iodothyronine deiodinase activity, as measured by radioimmunoassay. Endocrinology. 124:740-745.

44. Eelkman Rooda SJ, Kaptein E, Visser TJ. 1989 Serum triiodothyronine sulfate in man measured by radioimmunoassay. J Clin Endocrinol Metab. 69:552-556.

45. Polk DH, Reviczky A, Wu SY, Huang WS, Fisher DA. 1994 Metabolism of sulfoconjugated thyroid hormone derivatives in developing sheep. Am J Physiol 266:E892-E896.

46. Santini F, Chopra IJ, Wu SY, Solomon DH, Chua Teco GN. 1992 Metabolism of 3,5,3'-triiodothyronine sulfate by tissues of the fetal rat: a consideration of the role of desulfation of 3,5,3'-triiodothyronine sulfate as a source of T3. Pediat Res. 31:541-544.

47. Sato K, Robbins J. 1980 Thyroid hormone metabolism in cultured monkey hepatocarcinoma cells. Monodeiodination activity in relation to cell growth. J Biol Chem. 255:7347-7352.

48. Heinrich PC, Castell JV, Andus T. 1990 Interleukin-6 and the acute phase response. Biochem J. 265:621-636.

49. Docter R, Krenning EP, de Jong M, Hennemann G. 1993 The sick euthyroid syndrome: changes in thyroid hormone serum parameters and hormone metabolism. Clin Endocrinol (Oxf). 39:499-518.

50. Campos-Barros A, Hoell T, Musa A, et al. 1996 Phenolic and tyrosyl ring iodothyronine deiodination and thyroid hormone concentrations in the human central nervous system. J Clin Endocrinol Metab. 81:2179-2185. 